\title{
PELATIHAN METODE MEMBACA SQ3R UNTUK SISWA MADRASAH TSANAWIAH RAUDHATUSYUBBAN
}

\section{SQ3R Reading Method Training for Tsanawiah Raudhatusyubban Madrasah Students}

\section{Istiqamah* \\ Sri Normuliati}

Universitas Muhammadiyah

Banjarmasin, Banjarmasin,

Kalimantan Selatan, Indonesia

*email: iscutebibeh@gmail.com

\section{Kata Kunci:}

Madrasah

Metode Membaca

SQ3R

Keywords:

Madrasah

Reading Method

SQ3R

\begin{abstract}
Abstrak
Pengabdian ini bertujuan untuk meningkatkan minat membaca siswa madrasah tsanawiah atau setara dengan Sekolah Menengah Pertama (SMP) dengan teknik membaca SQ3R yang dapat diterapkan dalam membaca buku pelajaran. Metode kegiatan yang digunakan dalam pengabdian ini dalam bentuk pelatihan/ workshop dan hasil pelatihan disimulasikan langsung kepada masing-masing siswa melalui tahapan (I) Survei (2) Question/ pertanyaan (3) Read/ membaca (4) Recite/ Recall/ mengulang kembali/ menceritakan kembali dan (5) Review/ mengulas/ ulasan. Peserta pelatihan adalah siswa-siswi dari Madrasah Tsanawiah Raudhatusyuban yang berjumlah 26 orang serta melibatkan guru yang berjumlah 2 orang. Hasil dari kegiatan pengabdian ini menunjukkan bahwa kemampuan membaca siswa madrasah tsanawiah atau setara dengan SMP masih sangat rendah sehingga dengan adanya pelatihan membaca dengan metode SQ3R ini diharapkan dapat meningkatkan minat dan keterampilan membaca siswa.
\end{abstract}

\begin{abstract}
This service aims to increase reading interest in tsanawiah madrasah students or equivalent to junior high schools (SMP) with SQ3R reading techniques that can be applied in reading textbooks. The method of activities used in this service in the form of training/workshops and training results are simulated directly to each student through stages (I) Survey (2) Questions/questions (3) Read/read (4) Recite/Recall/Repeat/Retell and (5) Review/review/review. The trainees were 26 students from Tsanawiah Raudhatusyuban Madrasah and involved two teachers. The results of this service show that the reading ability of students of the Tsanawiah madrasah or equivalent to junior high school is still deficient so that the existence of reading training with the SQ3R method is expected to increase students' interest and reading skills.
\end{abstract}

(C) 2019 The Authors. Published by Institute for Research and Community Services Universitas Muhammadiyah Palangkaraya. This is Open Access article under the CC-BY-SA License (http://creativecommons.org/licenses/by-sa/4.0/). DOI: https://doi.org/10.33084/pengabdianmu.v4il.552.

\section{PENDAHULUAN}

Membaca adalah kebutuhan siswa dalam belajar. Di era digital saat ini, banyak siswa yang menganggap membaca buku merupakan hal yang membosankan, karena mereka lebih mudah membaca melalui smartphone. Saat ini bahkan siswa sudah mulai belajar dengan menggunakan aplikasi, yang hanya cukup dengan menonton video pembelajaran. Tidak dapat dipungkiri, membaca media sosial juga menjadi salah satu kegemaran siswa saat ini, padahal informasi dari media sosial itu belum tentu benar (Hapsari, 20I7).

Kehidupan manusia saat ini sangat dekat dengan smartphone, bahkan membaca buku pun dapat dilakukan melalui beragam aplikasi, Disadari atau tidak, sesungguhnya ada bahaya yang mengintai apabila kita selalu menggunakan smartphone, misalnya seperti sakit mata merah karena terlalu lama menatap layar telepon genggam (Bavelier et al., 20II). Oleh karena itu, khususnya bagi siswa ada baiknya dalam belajar tetap menggunakan buku sebagai sumber bacaan yang utama. Agar dapat membaca buku secara efektif dan efesienm ada berbagai macam metode/ teknik membaca yang dapat digunakan oleg siswa untuk belajar, salah satunya adalah dengan metode SQ3R (Hidayat et al., 20I8).

Membaca merupakan suatu kegiatan kognitif yang dilakukan dengan tujuan untuk memperoleh informasi 
dari media tulisan. Bagi seorang siswa yang tugas utamanya belajar, maka kegiatan membaca merupakan kegiatan yang wajib dilakukan. Siswa beringkali menemukan kendala dalam membaca buku pelakaran, karena kurangnya minat baca dan kurangnya keterampilan dalam membaca (Ekadini \& Rukmini, 2018; Serdyukov, 2017).

Minat baca merupakan dorongan untuk memahami kata demi kata dan isi yang terkandung di dalam teks bacaan tersebut, sehingga pembaca dapat memahami hal-hal yang dituangkan dalam bacaan itu (Dalman, 20I4). Agar siswa memiliki minat baca yang tinggi, maka orang tua atau guru perlu menumbuhkan minat tersebut. Salah satu cara yang bisa dilakukan agar siswa berminat membaca adalah dengan mengajarkan kepada siswa kegiatan membaca yang mudah dan menyenangkan. Pendekatan yang bisa dilakukan adalah dengan mengajarkan metode membaca SQ3R. Apabia siswa sudah terbiasa membaca, maka ia akan gemar membca dan menjadikan membaca sebagai kebutuhan hidupnya, Membaca memerlukan keterampilan agar informasi atau pesan dapat diperoleh dan dipahami dengan baik dan benar. Metode SQ3R (Survei, question, read, recite/recall, dan review) adalah salah satu metode atau teknik membaca untuk memahami isi bacaan yang menggunakan langkah-langkah secara sistematis dalam pelaksanaannya. Metode ini dapat membantu siswa dalam kegiatan belajar, agar lebih mudah menemukan atau memahami informasi yang diiinginkan dan menghemar waktu ketika membaca. Di samping untuk membaca buku pelajaran, metode ini juga dapay digunakan oleh siswa pada saat mengerjakan tugas dari guru (Muchtar \& Irmawati, 2017).

\section{METODOLOGI}

Pelaksanaan pengabdian masyarakat dilaksanakan selama I hari yaitu pada hari Kamis, tanggal 20 Seotember 2018, melibatkan siswa kelas IX yang berjumlah 26 orang bertempat di Madrasah Tsanawiah
Raudhatusyubban Kabupaten Banjar. Kegiatan ini dilaksanakan dengan metode ceramah, diskusi, serta tanya jawab dan juga praktik membaca dengan metode SQ3R secara langsung. Setelah dipraktikan, peserta pelatihan akan mendapat masukan dari pemateri tentang bagaimana metode membaca dengan teknik SQ3R ini.

Tabel I. Tahapan Kegiatan Pelatihan Metode Membaca dengan Teknik SQ3R

\begin{tabular}{llll}
\hline No. & Kegiatan & Metode & Keterangan \\
\hline I. & $\begin{array}{l}\text { Paparan materi dari } \\
\text { pemateri }\end{array}$ & Ceramah & pemateri \\
\hline 2. & Tanya jawab/ diskusi & $\begin{array}{l}\text { Tanya } \\
\text { jawab dan } \\
\text { diskusi }\end{array}$ & $\begin{array}{l}\text { Pemateri dan } \\
\text { peserta }\end{array}$ \\
\hline 3. & $\begin{array}{l}\text { Praktik Membaca } \\
\text { dengan metode }\end{array}$ & Praktik & Pemateri dan \\
SQ3R peserta
\end{tabular}

\section{HASIL DAN PEMBAHASAN}

Hasil yang ingin dicapai dalam kegiatan pengabdian ini adalah meningkatnya minat dan keterampilan membaca siswa di madrasah tsanawiah Raudhatussyubban. Pelatihan ini sangat bernilai dan bermanfaat bagi siswasiswa, khususnya kelas IX yang akan mengikuti Ujian Akhir Nasional (UAN), agar dapat diterapkan dalam 
menjawab soal-soal UAN nantinya dan dalam mengerjakan tugas-tugas sekolah. Di sekolah ini padahal sudah tersedia perpustakaan yang cukup memadai akan tetapi belum dimaksimalkan oleh siswa-siswa di sini karena kurangnya minat membaca mereka. Diharapkan setelah pelatihan ini mereka mendapatkan manfaat dan minat serta keterampilan membaca yang lebih tinggi.

Membaca merupakan aktivitas yang dapat memberikan manfaat yang besar namun karena kurangnya minat membaca ini maka aktivitas ini seringkali dianggap sebelah mata dan seringkali diabaikan. Hal yang harus dipahami sebelum membaca itu adalah tujuan dari membaca itu sendiri. Tujuan dari membaca akan memudahkan kita untuk mencapai tujuan/ target dalam membaca. Setelah menentukan tujuan yang sesuai, maka akan mudah bagi kita untuk menyesuaikan teknik atau metode membaca yang tepat dan sesuai dengan tujuan dari membaca.

Misalnya, kita bertujuan membaca untuk menemukan sesuatu hal yang tidak kita ketahui di dalam buku atau kamus. Maka teknik atau metode yang tepat dalam membaca adalah membaca dengan teknik scanning atau membaca memindai. Kemudian, jika tujuan kita membaca adalah agar dapat menghemat waktu, maka teknik atau metode yang digunakan adalah teknik membaca cepat.

Oleh karena itu, penting bagi kita untuk mengetahui dan memahami tujuan dari membaca kita untuk apa. Setelah kita dapat menentukan tujuan dari membaca maka akan dengan mudah kita menentukan metode/teknik dalam membaca yang sesuai dengan tujuan kita. Begitu juga dengan teknik membaca SQ3R ini, biasanya teknik membaca ini digunakan untuk para siswa untuk memudahkan dalam memahami suatu pelajaran atau buku pelajaran. Sehingga, apa yang sebelumnya mungkin kurang jelas ketika guru menjelaskan dapat dimaksimalkan dengan membaca dengan teknik SQ3R ini.
Sebelum kita mengajarkan teknik membaca SQ3R ini ada baiknya kita menanamkan pentingnya membaca dan membangun minat membaca kepada para siswa. Sehingga minat membaca yang sebelumnya kurang maksimal dapat lebih ditingkatkan dengan kita menanamkan pentingnya membaca ini.

Dalman (2014) menyebutkan bahwa minat membaca sangat ditentukan oleh beberapa faktor, yaitu:

I. Faktor lingkungan keluarga

Di tengah kesibukan sebaiknya orang tua menyisihkan waktu untuk menemani anaknya membaca buku, dengan begitu orang tua dapat memberikan contoh yang baik dalam meningkatkan kreativitas membaca anak.

2. Faktor kurikulum dan pendidikan sekolah yang kurang kondusif

Kurikulum yang tidak secara tegas mencantumkan kegiatan membaca dalam suatu bahan kajian, serta para tenaga pendidikan baik sebagai guru, dosen, maupun para pustakawan yang tidak memberikan motivasi pada peserta didik bahwa membaca itu penting untuk menambah ilmu pengetahuan, melatih berpikir kritis, menganalisis persoalan, dan sebagainya.

3. Faktor insfratruktur masyarakat yang kurang mendukung peningkatan minat baca masyarakat Kurangnya minat baca masyarakat ini bisa dilihat dari kebiasaan sehari-hari. Banyak orang yang lebih memilih menghabiskan uang demi hal lain daripada membeli buku.

4. Faktor keberadaan dan kejangkauan bahan bacaan Sebaiknya pemerintah daerah mengadakan program perpustakaan keliling atau perpustakaan tetap di tiap-tiap daerah agar lebih mudah dijangkau oleh masyarakat.

Setelah memahami minat membaca dan pentingnya membaca peserta pelatihan diharapkan mampu menyesuaikan dengan tujuan membaca pada masingmasing teknik atau metodenya. 
Membaca adalah suatu proses yang dilakukan serta dipergunakan oleh pembaca untuk memperoleh pesan yang hendak disampaikan oleh penulis melalui media kata-kata/ bahasa tulis. Membaca merupakan suatu kegiatan atau proses kognitif yang berupaya untuk menemukan berbagai informasi yang terdapat dalam tulisan. Hal ini berarti membaca merupakan proses berpikir untuk memahami isi teks yang dibaca (Dalman, 2014).

Teknik membaca dengan metode SQ3R (Dalman, 2014) dijabarkan sebagai berikut:

I. Teknik SQ3R adalah salah satu teknik membaca untuk memahami isi bacaan dengan menggunakan langkah-langkah secara sistematis dalam pelaksanaannya.

2. Teknik membaca dengan SQ3R merupakan proses membaca yang terdiri atas lima langkah, yaitu survey, question, read, recite (recall), dan review.

3. Teknik SQ3R dapat digunakan untuk membaca buku pelajaran.

4. Teknik SQ3R ini sangat efektif digunakan untuk mengerjakan tugas bagi para siswa.

Tahapan membaca dengan teknik SQ3R terdiri dari tahap-tahap sebagai berikut:

\section{Survey}

Tinjau: Survey atau prabaca adalah teknik untuk mengenal bahan yang dibaca.

a. Survey atau prabaca hanya dilakukan beberapa menit

b. Survey dilakukan dengan sistematis agar dapat menemukan dengan cepat menemukan ide-ide penting dan organisasi bahan

c. Jenis survey: Survey buku, survey bab, survey artikel, dan survey kliping

2. Question

Tanya: Langkah yang memerlukan pembaca mengutamakan suatu ciri soal setelah mendapati teks tersebut berkaitan dengan keperluan tugasnya. a. Bersamaan pada saat survey ajukan pertanyaan sebanyak-banyaknya tentang isi bacaan itu

b. Gunakan kata siapa, apa, kapan, di mana, bagaimana, dan mengapa

3. Read

Baca: Setelah melewati tahap survey dan timbul beberapa pertanyaan yang Anda harapkan akan mendapat jawaban di bacaan yang Anda hadapi.

a. Ada dua hal yang perlu diperhatikan dalam tahapan ini yaitu (I) jangan membuat catatan (2) jangan membuat tanda-tanda dalam bacaan

b. Harus konsentrasi dan fokus untuk membaca saja

4. Recite/Recall

Menceritakan Kembali: Pada tahap ini Anda diharapkan untuk dapat mengutarakan kembali atau menceritakan kembali apa yang sudah dibaca. Pada tahap ini perlu dilakukan dengan baik sehingga si pembaca benar-benar memahami apa yang dibacanya

5. Review

Ulasan: mengulang kembali setelah membaca teks tersebut.

a. Sekalipun pada waktu membaca $85 \%$ kita menguasai isi bacaan kemampuan kita dalam waktu 8 jam untuk megingat detail yang penting $40 \%$.

b. Si pembaca perlu menulis kembali hal-hal yang dianggap penting.

Berdasarkan pendapat dari para ahli di atas tentang teknik atau metode SQ3R di atas dapat disimpulkan bahwa metode SQ3R ini dapat digunakan untuk tujuan siswa agar lebih memahami pelajaran yang diajarkan di sekolah.

Dari hasil kegiatan pelatihan membaca dengan metode SQ3R ini menunjukkan bahwa adanya peningkatan minat dan keterampilan membaca yang dimiliki para siswa kelas IX yang ada di Madrasah Tsanawiah Raudhatussyubban. 
Keutamaan membaca dengan metode SQ3R ini adalah:

I. Teknik ini sangat efektif untuk mengerjakan tugas bagi para siswa

2. Teknik ini sangat efektif untuk memahami isi bacaan

3. Teknik ini lebih efektif jika digunakan untuk membaca buku di luar kelas, misalnya untuk mengerjakan tugas di rumah (PR)

Dalam melakukan pelatihan ini pemateri meminta peserta untuk mempraktekkan secara langsung teknik membaca SQ3R ini.

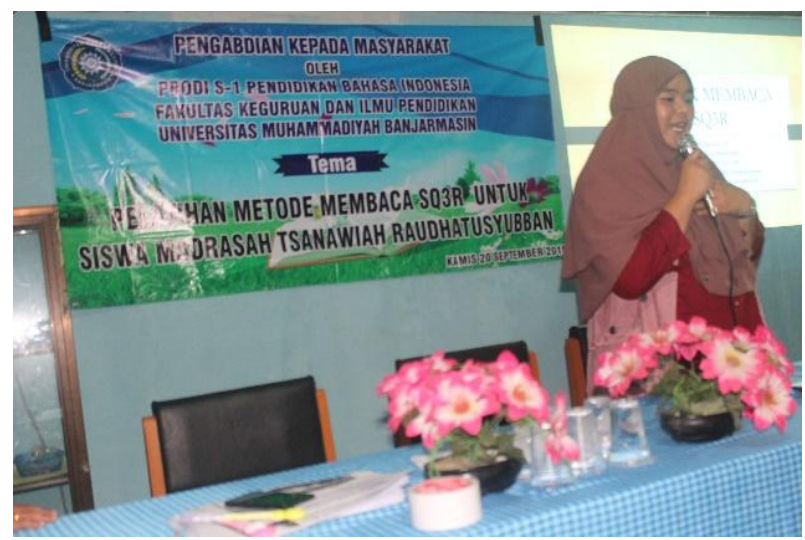

Gambar I. Pemateri Memaparkan Pentingnya

Membaca dan Memotivasi Siswa agar Menumbuhkan

Minat Membaca serta Mejelaskan tentang Metode Membaca dengan Metode SQ3R

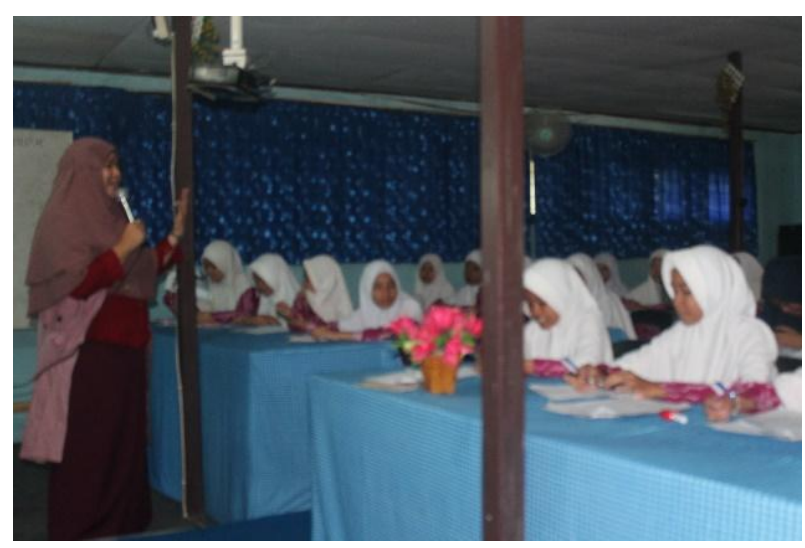

Gambar 2. Siswa Mempraktekkan Metode Membaca dengan Teknik SQ3R

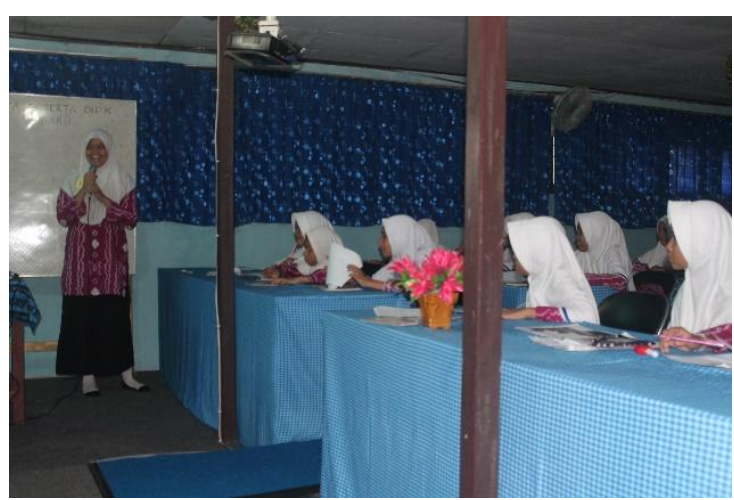

Gambar 3. Siswa Mencoba Menceritakan Kembali (Recite/Recall) Apa yang Sudah Dibacanya

\section{KESIMPULAN}

Kegiatan pengabdian ini dalam bentuk pelatihan yang dilaksanakan telah mampu meningkatkan minat dan keterampilan membaca siswa Madrasah Tsanawiah Raudhatussyubban dengan metode membaca SQ3R. Kegiatan ini cukup antusias diikuti oleh para siswa di sekolah ini. Kegiatan ini cukup sukses berjalan sesuai rencana. Kegiatan pengabdian ini juga masih memungkinkan ada kelanjutannya pada kesempatan selanjutnya dengan lingkup yang lebih luas.

\section{REFERENSI}

Bavelier, D., Green, C.S., \& Dye, M.W.G. $201 \mathrm{I}$. Children, wired - for better and for worse. Neuron. 67(5):692-70I.

Dalman. 2014. Keterampilan Membaca. Jakarta: Raja Grafindo Persada.

Ekadini, L. \& Rukmini, D. 2018. Cognitive and StructureProposition-Evaluation Strategies in Teaching TOEFL Reading Comprehension to High Low Motivated Students. English Education Journal. 8(3):308-316.

Hapsari, A.E. 2017. Penerapan Model Pembelajaran Kooperatif Tipe Numbered Heads Together Berbantuan Media Interaktif Untuk Meningkatkan Aktivitas dan Prestasi Belajar Siswa. SCHOLARIA: Jurnal Pendidikan dan Kebudayaan. 7(I): I-9.

Hidayat, N., Suyanto, I., Susiani, T.S. 2018. Penggunaan Metode SQ3R dalam Peningkatan Pemahaman Membaca Cerita Anak pada 
Siswa Kelas V SD Negeri Jatimalang. Kalam Cendekia: Jurnal Ilmiah Kependidikan. 6(4): I-5.

Muchtar, N. \& Irmawati. 2017. Penerapan Metode SQ5R (Survey, Question, Read, Recite, Record, Review, Reflect) untuk Meningkatkan Keterampilan Membaca Teks Bahasa Inggris. IDEAS: Journal on English Language Teaching and Learning, Linguistics and Literature. 5(I): I19.

Serdyukov, P. 2017. Innovation in education: what works, what doesn't, and what to do about it? Journal of Research in Innovative Teaching \& Learning. I0(I):4-33. 